\title{
EVALUASI PENERAPAN SISTEM DAN PROSEDUR PENERBITAN SURAT PERINTAH MEMBAYAR UANG PERSEDIAAN PADA BADAN PENANGGULANGAN BENCANA DAERAH KOTA BITUNG
}

\author{
Astika Julia Syafira $^{1}$, Harijanto Sabijono ${ }^{2}$, Priscillia Weku ${ }^{3}$ \\ 1,2,3 Jurusan Akuntansi, Fakultas Ekonomi dan Bisnis, Universitas Sam Ratulangi, Jl. Kampus Bahu, Manado \\ 95515, Indonesia \\ E-mail: astikajsyafira@gmail.com
}

\begin{abstract}
The aim of this research is to know whether the system and procedures for issuing warrants paying the money supply at The Bitung Emergency Management Agency (BPBD), was suitable with The Regulation of the Minister of Home Affairs No. 21 of 2011 about regional financial management. This type of research is descriptive with qualitative approach. The data collecting techniques done were interview and documentation. The steps taken to analyze the acquired data was done is evaluate the application of the system and procedure for issuing warrants paying the money supply based on The Regulation Of The Minister Of Home Affairs No. 21 of 2011. The results showed that the system and procedures for issuing warrants paying the money supply at The Bitung Emergency Management Agency was suitable with The Regulation of the Minister of Home Affairs No. 21 of 2011. It is recommended that the leadership of The Bitung Emergency Management Agency improve and maintain the systems and procedures for the issuance of cash money supllies, especially the issuing warrants paying the money supply.
\end{abstract}

Keywords: systems; procedure; warrant pay; the money supply

\section{PENDAHULUAN}

Pemerintah Daerah diwajibkan menyusun laporan pertanggungjawaban yang menggunakan sistem akuntansi yang diatur oleh pemerintah pusat agar terciptanya Good Governance dalam bentuk Undang-Undang dan Peraturan Pemerintah yang bersifat mengikat seluruh Pemerintah Daerah yang bertujuan untuk meningkatkan akuntabilitas dan transparansi dalam pengelolaan keuangan pemerintah daerah. Oleh karena itu, dibuatlah sistem dan prosedur yang telah ditetapkan sebelumnya oleh pemerintah yang tertuang dalam Undang-Undang serta Peraturan-Peraturan yang terkait berupa Peraturan Menteri Dalam Negeri (Permendagri) Nomor 13 Tahun 2006 dan perubahan keduanya Permendagri Nomor 21 Tahun 2011 tentang Pedoman Pengelolaan Keuangan Daerah sebagai pedoman dasar dalam pengelolaan keuangan baik penerimaan maupun pengeluaran kas dan untuk lebih meningkatkan transparansi dan akuntabilitas dan menghindari segala penyelewengan, penggelapan, penipuan, serta pemborosan harta kekayaan negara terhadap kas.

Berdasarkan Permendagri Nomor 13 Tahun 2006 Pasal 233) maka Sistem Akuntansi Pemerintahan Daerah terdiri atas prosedur penerimaan kas, prosedur pengeluaran kas, prosedur akuntansi asset tetap/barang milik daerah, dan prosedur akuntansi selain kas. Sistem akuntansi pengeluaran kas yaitu serangkaian proses yang dimulai dari pencatatan, penggolongan, dan peringkasan transaksi dan kejadian keuangan serta pelaporan keuangan dalam rangka pertanggungjawaban pelaksanaan APBD yang berkenaan dengan pengeluaran kas pada Satuan Kerja Perangkat Daerah (SKPD) atau Satuan Kerja Pengelola Keuangan Daerah (SKPKD) yang dapat dilaksanakan secara manual maupun terkomputerisasi (Halim, 2012:84). 
Surat Perintah Membayar Uang Persediaan adalah dokumen yang diterbitkan oleh Pengguna Anggaran atau Kepala SKPD setelah surat permintaan pembayaran dan untuk penerbitan Surat Perintah Pencairan Dana (SP2D) atas beban-beban pengeluaran Dokumen Pelaksanaan Anggaran SKPD (DPA-SKPD) yang digunakan sebagai uang persediaan untuk mendanai kegiatan operasional (Permendagri Nomor 21 Tahun 2011 Pasal 71). Adapun beberapa hal yang harus diperhatikan dalam setiap prosedur tersebut adalah dokumen yang digunakan, fungsi yang terkait, laporan yang dihasilkan serta uraian teknis prosedur apakah telah sesuai dengan peraturan yang berlaku (Onibala et al., 2014). Hal ini disebabkan masih terdapat kendala saat proses penerbitan pengeluaran kas, baik dalam hal keterlambatan penerbitan ke Sistem Informasi Manajemen Daerah (SIMDA) maupun tugas dan wewenang yang masih ditangguhkan ke operator.

Badan Penanggulangan Bencana Daerah merupakan sebuah Lembaga Pemerintah Non Departemen yang mempunyai tugas membantu Presiden Republik Indonesia dalam mengkoordinasikan perencanaan dan pelaksanaan kegiatan penanganan dan bencana dan kedaruratan secara teratur, dan juga melaksanakan penanganan bencana dan kedaruratan mulai dari sebelum, pada saat, dan setelah terjadi bencana yang meliputi pencegahan, kesiapsiagaan, penanganan darurat, dan pemulihan sehingga Badan Penanggulangan Bencana Daerah memerlukan suatu sistem operasional kegiatan guna terlaksananya program kerja tersebut. Salah satu dari berbagai jenis program kerja tersebut yaitu pengeluaran kas, dimana dalam mengelola keuangan daerah, BPBD Kota Bitung harus memiliki sistem dan prosedur memadai sebagai salah satu tindakan penangkalan terhadap adanya penyalahgunaan dana.

Uang persediaan adalah dana awal yang menggambarkan pengelolaan keuangan pada Badan Penanggulangan Bencana Daerah Kota Bitung di awal tahun anggaran dengan pengelolaan keuangan yang baik dan sesuai dengan Undang-Undang Nomor 17 Tahun 2003 tentang Pengelolaan Keuangan Negara dan Permendagri Nomor 21 Tahun 2011 tentang Pedoman Pengelolaan Keuangan Daerah. Pada penerapannya belum dapat dipastikan apakah semua Pemerintah Daerah dalam melaksanakan pengelolaan keuangan daerah telah mengacu pada sistem dan prosedur sesuai ketentuan perundang-undangan yang berlaku. Oleh sebab itu, perlu dilakukan evaluasi lebih lanjut terhadap penerapan sistem dan prosedur pengeluaran kas khususnya penerbitan Surat Perintah Membayar Uang Persediaan (SPM-UP) sebagai upaya nyata untuk mencegah penyalahgunaan dan penyelewengan dana.

\section{TINJAUAN PUSTAKA}

Konsep Akuntansi. Menurut Hery (2018:8), akuntansi didefinisikan sebagai sebuah sistem informasi yang memberikan laporan kepada para pengguna informasi akuntansi atau kepada pihak-pihak yang memiliki kepentingan terhadap hasil kinerja dan kondisi keuangan perusahaan. Aktivitas yang mendasar yakni identifikasi, pencatatan, dan pengkomunikasian peristiwa ekonomi sesuai dengan aktivitas usahanya dan mencatat peristiwa untuk menyediakan catatan kegiatan keuangan adalah pengertian dari akuntansi (Weygandt et al., 2016:2). Akuntansi merupakan proses identifikasi, pengukuran, dan komunikasi informasi keuangan tentang objek ekonomi kepada pihak-pihak yang berkepentingan (Weygandt et al., 2010:4). Putra (2019:15) menyatakan bahwa akuntansi diartikan sebagai sistem informasi yang menyediakan laporan untuk para pemangku kepentingan mengenai aktivitas ekonomi dan kondisi perusahaan.

Akuntansi pemerintahan. Akuntansi pemerintahan terdiri dari serangkaian prosedur, mulai dari proses pengumpulan data, pencatatan, pengelompokkan, dan peringkasan atas transaksi atau kejadian keuangan serta pelaporan keuangan dalam rangka pertanggungjawaban pelaksanaan APBD (Permendagri Nomor 13 Tahun 2006 pasal 1 ayat 5). Salah satu bidang akuntansi yang berkaitan dengan lembaga pemerintahan biasa disebut dengan Akuntansi Pemerintahan. Akuntansi pemerintahan mempunyai keunikan khusus yaitu 
lebih menekankan pada pencatatan pelaksanaan anggaran negara serta pelaporan realisasinya (Riyanto dan Agus, 2015:3). Akuntansi pemerintahan adalah bentuk laporan keuangan pemerintah sebagai bentuk pertanggungjawaban atas penggunaan dana publik atau APBD yang disajikan sesuai dengan Standar Akuntansi Pemerintah sehingga akuntansi pemerintahan adalah suatu aktivitas pemberian jasa untuk membekali informasi keuangan pemerintah atas dasar proses pencatatan, pengklasifikasian, dan pengikhtisaran suatu transaksi keuangan pemerintah serta penafsiran atas informasi keuangan tersebut.

Sistem akuntansi pemerintah daerah. Sistem Akuntansi Pemerintah Daerah terdiri atas (Permendagri Nomor 13 Tahun 2006 pasal 232 ayat (1)); prosedur akuntansi penerimaan kas, prosedur akuntansi pengeluaran kas, prosedur akuntansi aset tetap/barang milik daerah, dan prosedur akuntansi selain kas. Sistem Akuntansi Pemerintah Daerah (SAPD) merupakan kumpulan sistem dari prosedur, penyelenggara, peralatan dan elemen lain untuk menciptakan fungsi akuntansi dari analisis transaksi sampai dengan pelaporan keuangan di lingkup organisasi pemerintah daerah (Permendagri No. 64 Tahun 2013 pasal 1 ayat 8). Sistem akuntansi pemerintah daerah dilaksanakan oleh Pejabat Pengelola Keuangan Daerah (PPKD) pada Satuan Kerja Pengelola Keuangan Daerah (SKPKD), dan sistem akuntansi SKPD dilaksanakan oleh Pejabat Penatausahaan Keuangan (PPK) SKPD (Wati et al., 2015:410).

Definisi sistem dan prosedur. Sistem merupakan gabungan suatu benda nyata atau abstrak yang terdiri dari bagian-bagian yang saling berkaitan, berketergantungan, yang secara menyeluruh bersatu dalam satu kesatuan untuk mencapai tujuan tertentu secara efektif dan efisien (Hutahaean, 2014:1). Sistem memiliki arti komponen-komponen yang dimiliki unsur keterkaitan antara satu dan dengan lainnya. Prosedur merupakan aktivitas atau cara kerja dalam segala tindakan atau proses (Machali, 2009:91). Prosedur adalah langkah-langkah aturan yang harus dipatuhi oleh masing-masing unit dalam rangka kerjasama melancarkan arus informasi. Prosedur umumnya melingkupi kegiatan yang harus dilakukan pada suatu waktu atau periode tertentu dengan arah dan tujuan tertentu, misalnya prosedur penerbitan Surat Perintah Membayar, dimana terdapat aturan mengenai langkah kegiatan yang harus dikerjakan atau dipenuhi dari kelengkapan dokumen, membuat rancangan SPM, dan sebagainya.

Sistem dan prosedur penerbitan surat perintah membayar uang persediaan. Surat Perintah Membayar (SPM) merupakan dokumen yang diterbitkan dan digunakan oleh Pengguna Anggaran dan dipakai untuk penerbitan SP2D atas beban pengeluaran DPA-SKPD (Permendagri Nomor 21 Tahun 2011 pasal 1 ayat 70). Proses penerbitan SPM merupakan tingkatan penting dalam penatausahaan pengeluaran yang merupakan tahap lanjutan dari proses pengajuan Surat Perintah Pembayaran atau SPP (Kapoh et al., 2015). Proses ini mulai sejak dengan pengujian atas SPM yang diajukan baik dari segi kelengkapan dokumen SPP maupun kebenaran pengisian dokumen tersebut. SPM dapat diterbitkan apabila pengeluaran yang diminta atau ditagih tidak melebihi pagu anggaran yang tersedia atau ditetapkan serta didukung dengan kelengkapan dokumen sesuai peraturan perundangan yang berlaku (Korobu et al., 2016:796). Adapun pihak yang terkait dalam kegiatan Penerbitan Surat Perintah Membayar, yaitu:

1. Penatausahaan Keuangan (PPK-SKPD). Pada kegiatan penerbitan SPM-UP, PPK SKPD memiliki tugas sebagai berikut: (1) menguji SPP beserta kelengkapan dokumennya; (2) membuat rancangan SPM atas SPP yang telah diuji kelengkapan dan kebenarannya dan mengajukannya ke Pengguna Anggaran (PA); (3) bila SPP yang diajukan oleh Bendahara Pengeluaran SKPD tidak lengkap atau tidak sesuai maka PPK-SKPD menerbitkan Surat Penolakan SPM; dan (4) membuat register SPM.

2. Pengguna Anggaran. Pada kegiatan penerbitan SPM-UP, Pengguna Anggaran memiliki tugas yaitu: (1) mengotorisasi dan menerbitkan SPM; dan (2) bila SPP yang diajukan 
Bendahara SKPD tidak lengkap maka Pengguna Anggaran mengotorisasi Surat Penolakan SPM yang diterbitkan PPK-SKPD.

\section{METODE PENELITIAN}

Jenis data. Adapun jenis pengambilan data yang digunakan dalam penelitian ini, yaitu: (1) data kualitatif, dimana data yang dikumpulkan berupa hasil wawancara dengan informan tentang gambaran umum lembaga, struktur organisasi, dan mengenai penerapan sistem dan prosedur penerbitan Surat Perintah Membayar Uang Persediaan di Badan Penanggulangan Bencana Daerah Kota Bitung; dan (2) data kuantitatif, yaitu hasil dari dokumentasi berupa dokumen-dokumen Surat Perintah Membayar Uang Persediaan (SPMUP) di Penanggulangan Bencana Daerah Kota Bitung yang disajikan dalam bentuk angka.

Sumber data. Sumber data yang digunakan dalam penelitian ini adalah data primer. Data primer adalah data yang didapat dari hasil wawancara secara langsung dari subjek penelitian yaitu pegawai di Badan Penaggulangan Bencana Daerah Kota Bitung. Adapun yang menjadi data primer adalah sejarah lembaga, struktur organisasi, visi dan misi lembaga, dan data mengenai sistem dan prosedur penerbitan Surat Perintah Membayar Uang Persediaan (SPM UP).

Metode dan proses analisis. Metode analisis data yang digunakan adalah metode analisis deskriptif. Metode ini bertujuan untuk menguraikan, membandingkan, memberikan gambaran lembaga dan menerangkan suatu data yang kemudian dianalisis sehingga dapat membuat suatu kesimpulan sesuai dengan informasi dan data yang telah dikumpulkan. Proses analisis data dalam penelitian ini, yaitu: (1) pengumpulan data berupa gambaran umum BPBD Kota Bitung, struktur organisasi, dan data mengenai penerbitan Surat Perintah Membayar Uang Persediaan (SPM-UP); (2) melakukan evaluasi penerapan sistem dan prosedur Penerbitan SPM-UP yang dipakai Badan Penanggulangan Bencana Daerah Kota Bitung; dan (3) menarik kesimpulan.

\section{HASIL PENELITIAN DAN PEMBAHASAN}

\subsection{Hasil penelitian}

Proses penerbitan SPM-UP merupakan langkah penting dalam penatausahaan pengeluaran yang merupakan tahap lanjutan dari proses pengajuan SPP-UP. Prosedur penerbitan SPM-UP pada Badan Penanggulangan Bencana Daerah Kota Bitung mencakup, penyusunan dokumen SPP-UP, pembuatan tagihan SPP-UP, pemeriksaan dokumen, sampai diterbitkan SPM dan SP2D nihil selama pengeluaran yang diminta tidak melebihi pagu anggaran. Penerbitan Surat Perintah Membayar Uang Persediaan (SPM-UP) hanya dilakukan setahun sekali oleh BPBD Kota Bitung yaitu di awal tahun atau triwulan pertama. Prosedur penerbitan SPM-UP di Badan Penanggulangan Bencana Daerah Kota Bitung adalah sebagai berikut:

a. Apabila SK Walikota tentang UP telah terbit maka Pengguna Anggaran yakni Kepala BPBD Kota Bitung menyerahkan SPD kepada Bendahara dan PPK-SKPD.

b. Berdasarkan SK-UP (SPD) dan SPJ maka Bendahara membuat SPP-UP beserta dokumen lainnya,yang terdiri dari: (1) Lembar verifikasi dokumen SPM yang ditandatangani oleh Pejabat Penatausahaan Keuangan SKPD sebanyak 2 rangkap asli; (2) Kuitansi Dinas sebanyak 4 rangkap asli (1 rangkap bermaterai); (3) Surat Perintah Membayar (SPM) sebanyak 4 rangkap asli; (4) Surat Permintaan Pembayaran UP (SPP-UP) sebanyak 4 rangkap asli; (5) Surat Permohonan Uang Persediaan; (6) Surat Pernyataan Uang Persediaan sebanyak 2 rangkap asli (1 rangkap bermaterai); (7) Surat Pernyataan Tanggung Jawab sebanyak 2 rangkap asli (1 rangkap bermaterai); dan (8) Peraturan Walikota Tentang Uang Persediaan (SK-UP). 
c. Bendahara Pengeluaran BPBD Kota Bitung menyerahkan SPP-UP beserta dokumen lain kepada PPK-SKPD BPBD Kota Bitung untuk diteliti.

d. SPP-UP yang dinyatakan lengkap akan dibuatkan Rancangan SPM oleh PPK-SKPD, dimana Penerbitan SPM paling lambat 2 hari kerja sejak SPP-UP diterima. Rancangan SPM yang telah terbit kemudian diberikan PPK SKPD kepada Pengguna Anggaran untuk diotorisasi. Jika SPP-UP dinyatakan tidak lengkap atau tidak sesuai maka PPK-SKPD akan menerbitkan Surat Penolakan Penerbitan SPM. Penolakan SPM diterbitkan paling lambat 1 hari kerja sejak SPP-UP diterima. Surat penolakan penerbitan SPM kemudian akan diserahkan kepada Bendahara Pengeluaran BPBD Kota Bitung agar Bendahara melakukan penyempurnaan SPP-GU dan kemudian diserahkan kepada PPK-SKPD untuk diteliti kembali.

BPBD Kota Bitung menerbitkan SPM-UP sejalan dengan ketentuan dalam Permendagri Nomor 13 Tahun 2006 dan perubahannya yang kedua Permendagri Nomor 21 Tahun 2011, dimana SPM-UP dapat diterbitkan jika pengeluaran yang diajukan tidak melebihi pagu anggaran yang tersedia dan didukung dengan kelengkapan dokumen sesuai peraturan perundangan sedangkan waktu untuk pelaksanaan penerbitan SPM paling lambat dua hari sejak SPP diterima. Apabila dokumen SPP ditolak, maka akan dikembalikan paling lambat satu hari sejak SPP diterima. Format Surat Perintah Membayar Uang Persediaan pada BPBD Kota Bitung telah mengikuti Format Surat Perintah Membayar sebagaimana dimaksud dalam Peraturan Menteri Dalam Negeri Nomor 21 Tahun 2011. Sistem dan prosedur pembentukan dan penggunaan uang persediaan yang dilaksanakan oleh BPBD Kota Bitung sudah sesuai yang terdiri atas: (a) penerbitan Surat Penyediaan Dana (SPD); (b) pengajuan Surat Permintaan Pembayaran Uang Persediaan (SPP UP); (c) penerbitan Surat Perintah Membayar Uang Persediaan (SPM-UP); (d) penerbitan Surat Perintah Pencairan Dana (SP2D); dan (e) penerbitan Surat Pertanggungjawaban (SPJ-UP). Tabel 1 menyajikan perbandingan prosedur penerbitan SPM-UP pada BPBD Kota Bitung dengan Peraturan Menteri Dalam Negeri Nomor 21 Tahun 2011.

Tabel 1. Perbandingan prosedur penerbitan SPM-UP di BPBD Kota Bitung dengan Peraturan Menteri Dalam Negeri Nomor 21 Tahun 2011

\begin{tabular}{|c|c|c|c|}
\hline Langkah & Pelaksana & Aktivitas & $\begin{array}{l}\text { Permendagri No. } 21 \\
\text { Tahun } 2011\end{array}$ \\
\hline 1 & PA & Menyerahkan SPD kepada Bendahara dan PPK-SKPD & Sesuai \\
\hline 2 & Bendahara & $\begin{array}{l}\text { Membuat SPP-UP beserta dokumen lainnya berdasarkan SPD dan } \\
\text { SPJ }\end{array}$ & Sesuai \\
\hline 3 & Bendahara & $\begin{array}{l}\text { Menyerahkan SPP-UP beserta dokumen pendukung kepada PPK- } \\
\text { SKPD }\end{array}$ & Sesuai \\
\hline 4 & PPK-SKPD & $\begin{array}{l}\text { Meneliti kelengkapan dokumen SPP-UP dengan SPD dan DPA- } \\
\text { SKPD }\end{array}$ & Sesuai \\
\hline 5 & PPK-SKPD & Membuat rancangan SPM-UP jika dokumen dinyatakan lengkap & Belum sesuai \\
\hline 6 & PPK-SKPD & Menyerahkan rancangan SPM-UP kepada PA untuk diotorisasi & Sesuai \\
\hline 7 & PPK-SKPD & $\begin{array}{l}\text { Menerbitkan surat penolakan penerbitan SPM-UP jika dokumen } \\
\text { dinyatakan tidak lengkap }\end{array}$ & Sesuai \\
\hline 8 & PPK-SKPD & $\begin{array}{l}\text { Menyerahkan surat penolakan kepada bendahara agar melakukan } \\
\text { penyempurnaan SPP-GU yang kemudian diserahkan kepada PPK- } \\
\text { SKPD untuk diteliti kembali }\end{array}$ & Sesuai \\
\hline
\end{tabular}

Sumber : Data olahan, 2019

\subsection{Pembahasan}

Sistem dan prosedur penerbitan SPM-UP pada BPBD Kota Bitung telah sesuai dengan Peraturan Menteri Dalam Negeri Nomor 21 Tahun 2011, tetapi pada prakteknya proses penerbitan SPM-UP ke SIMDA belum sesuai karena seringkali ditangani oleh operator bidang, yang seharusnya merupakan tugas PPK-SKPD. Uang Persediaan (UP) adalah sejumlah uang yang disediakan untuk melaksanakan kegiatan operasional kantor sehari-hari kecuali belanja modal. Pemberian Uang Persediaan BPBD Kota Bitung 
berdasarkan Peraturan Walikota Bitung tentang pemberian dan batas jumlah Uang Persediaan, Ganti Uang Persediaan dan Tambahan Uang Persediaan di lingkungan Pemerintah Kota Bitung setiap awal tahun atau triwulan pertama, biasanya diterbitkan tanggal 1 hingga 10 Januari.

Sebelum Surat Perintah Membayar dibuat, usulan kebutuhan Uang Persediaan tersebut dilihat dari anggaran kas yang sudah disusun di awal tahun anggaran. Uang Persediaan di BPBD Kota Bitung tersebut dibatasi sebatas belanja barang dan jasa yang mendesak, belanja listrik, ATK, belanja perjalanan dinas selama uang persediaan mencukupi, cetak koran, servis kendaraan, air, internet, dan pemeliharaan alat pemotong. Belanja dengan nilai Rp 1,- sampai dengan Rp 4.999.999,- yang pembayarannya dilakukan dengan cara pembelian langsung (bukan melalui penyedia) dibayarkan melalui mekanisme UP/GU/TU dan yang digunakan sebagai alat bukti pembayarannya dan berita acara serah terima, dikecualikan untuk: (a) belanja gaji; (b) belanja honorarium; (c) insentif; (d) belanja jasa tenaga harian lepas; (e) belanja e-catalog; (f) belanja advertorial; (g) belanja yang didanai dari Dana Alokasi Khusus (DAK); dan (h) belanja modal.

Uang Persediaan di Bendahara dapat berupa kas di rekening BPBD Kota Bitung dan kas tunai. Saldo kas tunai di Bendahara paling tinggi Rp 5.000.000,00 (Lima Juta Rupiah) kecuali pada akhir tahun anggaran saldo dimaksud harus nihil. Kas di Bank digunakan untuk transaksi transfer lewat kasda online dan kas tunai di Bendahara digunakan untuk pembayaran kegiatan per transaksi tidak melebihi Rp 2.000.000,00 (Dua Juta Rupiah).

Pertanggungjawaban penggunaan Uang Persediaan harus dibuatkan SPP-GU dan SPM-GU dan diterbitkan Surat Perintah Pencairan Dana Ganti Uang (SP2D-GU) untuk mengisi kembali uang persediaan yang telah digunakan. Batas pertanggungjawaban penggunaan Uang Persediaan adalah bulan Desember tahun anggaran berjalan dan tidak ada pengisian kembali setelah terbit SP2D Nihil. Proses penerbitan SPM-UP di BPBD Kota Bitung dilakukan dengan cara mengatur dokumen-dokumen yang diperlukan, dan nota-nota yang keluar secara rutin sesuai SK Walikota tentang UP, contohnya nota telepon, listrik, dan lain-lain. Setelah itu nota-nota atau bukti transaksi tersebut dijumlahkan, kemudian akan dibuat tagihan sesuai SIMDA. Selanjutnya dibuat kuitansi berdasarkan jumlah tagihan dan diserahkan ke bagian keuangan untuk diperiksa, jika telah benar dan lengkap maka SPM dikeluarkan SP2D nihil.

\section{KESIMPULAN DAN SARAN \\ 5.1. Kesimpulan}

Berdasarkan hasil penelitian dan pembahasan yang telah diuraikan maka dapat disimpulkan bahwa sistem dan prosedur penerbitan Surat Perintah Membayar Uang Persediaan (SPM-UP) pada Badan Penanggulangan Bencana Daerah Kota Bitung, khususnya dalam penyusunan dokumen SPM-UP dan pemeriksaan dokumen pendukung, penerapannya telah sesuai dengan karakteristik pedoman pengelolaan keuangan daerah menurut Peraturan Menteri Dalam Negeri Nomor 21 Tahun 2011. Namun, pada prakteknya proses penerbitan belum sesuai karena masih ditangani oleh operator, dimana tugas tersebut harus dilakukan oleh PPK-SKPD.

\subsection{Saran}

Badan Penanggulangan Bencana Daerah Kota Bitung mempertahankan sistem dan prosedur pengeluaran kas uang persediaan (UP) dan diharapkan untuk tetap mengikuti peraturan yang berlaku jika terjadi perubahan peraturan dan meningkatkan sumber daya manusia agar dapat memaksimalkan kinerja pegawai pada BPBD Kota Bitung. 


\section{DAFTAR PUSTAKA}

Halim, A. (2012). Akuntansi sektor publik: Akuntansi keuangan daerah, Edisi 4. Jakarta: Salemba Empat.

Hery. (2018). Analisis laporan keuangan, Edisi ketiga. Jakarta: Grasindo.

Hutahaean, J. (2014). Konsep sistem informasi, Edisi 1. Yogyakarta: Deepublish.

Kapoh, I. T., Karamoy, H., \& Sabijono, H. (2015). Evaluasi pelaksanaan sistem dan prosedur pengeluaran kas uang persediaan pada Dinas Pariwisata dan Kebudayaan Kota Manado. Jurnal EMBA: Jurnal Riset Ekonomi, Manajemen, Bisnis dan Akuntansi, 3(1), 1053-1062. https://ejournal.unsrat.ac.id/index.php/emba/article/view/7810

Korobu, G. G., Pontoh, W., \& Tirayoh, V. Z. (2016). Analisis sistem dan prosedur penerbitan surat perintah membayar uang persediaan pada Dinas Pekerjaan Umum Kota Bitung. Jurnal Berkala Ilmiah Efisiensi, 16(3), 795-802. https://ejournal.unsrat.ac.id/index.php/jbie/article/view/13575

Machali, R. (2009). Pedoman bagi penerjemah: Panduan lengkap bagi anda yang ingin menjadi penerjemah profesional. Bandung: Kaifa.

Onibala, M. A., Ilat, V., \& Kalangi, L. (2014). Evaluasi sistem dan prosedur pengeluaran kas belanja langsung pada Dinas Pekerjaan Umum Kab. Minahasa. Jurnal EMBA: Jurnal Riset Ekonomi, Manajemen, Bisnis dan Akuntansi, 2(2), 1691-1701. https://ejournal.unsrat.ac.id/index.php/emba/article/view/5006

Peraturan Menteri Dalam Negeri Nomor 13 Tahun 2006 tentang Pedoman Pengelolaan Keuangan Daerah.

Peraturan Menteri Dalam Negeri Nomor 21 Tahun 2011 Perubahan Kedua Atas Peraturan Menteri Dalam Negeri Nomor 13 Tahun 2006 Tentang Pedoman Pengelolaan Keuangan Daerah.

Putra, I. M. (2019). Pengantar komplet akuntansi dan perpajakan. Yogyakarta: Quadrant.

Riyanto, \& P. Agus. (2015). Akuntansi pemerintah daerah berbasis akrual. Yogyakarta: Pustaka Pelajar.

Undang-Undang Republik Indonesia Nomor 17 Tahun 2003 tentang Keuangan Negara.

Wati, R., Morasa, J., \& Mawikere, L. (2015). Analisis sistem pelaporan belanja langsung tahun 2013 pada Badan Pengelola Keuangan dan Barang Milik Daerah Provinsi Sulawesi Utara. Jurnal EMBA: Jurnal Riset Ekonomi, Manajemen, Bisnis dan Akuntansi, $3(1)$, https://ejournal.unsrat.ac.id/index.php/emba/article/view/7122

Weygandt, J. J., Kieso, D. E., \& Kimmel, P. D. (2010). Pengantar akuntansi, Edisi ketujuh. Diterjemahkan oleh: Adhariani Desi, Diyanti Vera. Jakarta: Salemba Empat.

Weygandt, J. J., Kimmel, P. D., \& Kieso, D. E. (2016). Accounting principles, $12^{\text {th }}$ Edition. New York: John Willey \& Sons Inc. 